\title{
ON THE CAUCHY-SCHWARZ INEQUALITY AND SEVERAL INEQUALITIES IN AN INNER PRODUCT SPACE
}

\author{
Nicuşor Minculete
}

Abstract. The aim of this article is to prove new results related to several inequalities in an inner product space. Among these inequalities we will mention Cauchy-Schwarz inequality. Moreover, we will we obtain some applications of these inequalities.

Mathematics subject classification (2010): 46C05, 26D15, 26D10.

Keywords and phrases: Inner product space, Cauchy-Schwarz inequality.

\section{REFERENCES}

[1] J. M. AldAZ, Strengthened Cauchy-Schwarz and Hölder inequalities, JIPAM 10, 4 (2009), art. 116.

[2] A.-L. CAuchy, Cours d'Analyse de l'École Royale Polytechnique, I Partie, Analyse Algébrique, Paris, 1821, reprinted by Ed. Jacques Gabay, Paris, 1989.

[3] J. A. Clarkson, Uniformly convex spaces, Trans. Amer. Math. Soc. 40 (1936), 396-414.

[4] F. Dadipour, M. S. Moslehian, J. M. Rassias, S. E. Takahasi, Characterization of a generalized triangle inequality in normed spaces, Nonlinear Anal. 75 (2012), 735-741.

[5] S. S. DRAGOMIR, On Bessel and Grüss inequalities for orthonormal families in inner product spaces, Bulletin of the Australian Mathematical Society 69, 2 (2004), 327-340.

[6] S. S. Dragomir, Some Grüss type inequalities in inner product spaces, J. Inequal. Pure Appl. Math. 4 (2) (2003), art. 42.

[7] S. S. DRAGOMIR, A potpourri of Schwarz related inequalities in inner product spaces (II), J. Inequal. Pure Appl. Math. 7 (1) (2006), Article 14.

[8] C. F. DunKL, K. S. Wiliams, A simple norm inequality, The American Mathematical Monthly, vol. 71 (1964), 53-54.

[9] A. KeChriniotis, K. Delibasis, On generalizations of Grüss inequality in inner product spaces and applications, J. Inequal. Appl., vol. 2010, Article ID 167091, 18 pages.

[10] L. Maligranda, Simple Norm Inequalities, The American Mathematical Monthly, vol. 113 (2016), 256-260.

[11] J. L. MASSERA, J. J. SChÄFFER, Linear differential equations and functional analysis I, Ann. of Math. 67 (1958), 517-573.

[12] N. Minculete, R. PĂLtănea, Improved estimates for the triangle inequality, J. Inequal. Appl. 2017: 17 (2017).

[13] D. S. Mitrinović, J. PeČArić, A. M. FinK, Classical and New Inequalities in Analysis, Kluwer Academic, Dordrecht, 1992.

[14] M. S. Moslehian, F. Dadipour, R. Rajić, A. Marić, A glimpse at the Dunkl-Williams inequality, Banach J. Math. Anal. 5 (2011), 138-151.

[15] C. P. Niculescu, L.-E. Persson, Convex Functions and Their Applications. A Contemporary Approach, CMS Books in Mathematics, 2nd ed., Springer, 2018.

[16] J. PEČARIĆ, On Hua's inequality in real inner product spaces, Tamkang Journal of Mathematics, vol. 33, No. 3 (2002), 265-268.

[17] J. PEČARIĆ, B. TEPEŠ, Improvement of a Grüss type discrete inequality in inner product spaces, Bull. Math. Soc. Sc. Math. Roumanie, Tome 45 (93), no. 3-4 (2002), 199-208.

[18] J. PEČARIĆ, R. RAJIĆ, The Dunkl-Williams equality in pre-Hilbert $C^{*}$-modules, Lin. Algebra Appl. 425 (2007), 16-25. 
[19] J. PEČARIĆ, R. RAJIĆ, On some generalized norm triangle inequalities, Rad HAZU, vol. 515 (2013), 43-52. 